Marcin Laberschek (iD https://orcid/0000-0002-1081-5073

Uniwersytet Jagielloński

e-mail: marcin.laberschek@uj.edu.pl

\title{
Monumentalne wizerunki. Pomniki jako obrazy przedsiębiorstw
}

\author{
Abstract \\ Monumenatal Impressions. Monuments as Images of Enterprises
}

Many monuments that exist in the social space were erected on the initiative of enterprises. Monuments contain a symbolic message referring to various aspects of this type of organization, for example to their creation, to their achievements and successes, to what they do, to people who co-create them, to patrons and many others, sometimes less clear issues. Thus, monuments show enterprises from a chosen, specific point of view - they also create their images. This article presents which images of enterprises are produced by monuments and how this is done. Nine separate categories are listed: 1) images based on difficult experiences of enterprises; 2) images based on remembrances of enterprises; 3 ) images based on outstanding persons of enterprises; 4) images based on human work; 5) images based on the achievements of enterprises; 6) images based on the company's trademarks; 7) images based on the social involvement of enterprises; 8 ) images based on political involvement of enterprises; 9) images based on the metaphysical values of enterprises.

Keywords: monuments of the organization, monuments of enterprises, organization image, image management, cultural heritage of the organization

Słowa kluczowe: pomniki organizacji, pomniki przedsiębiorstw, wizerunek organizacji, zarządzanie wizerunkiem, dziedzictwo kulturowe organizacji 


\section{Uwag̉i wstępne}

Ze względu na swoją symboliczną wymowę pomniki budzą różnego rodzaju reakcje społeczne, czasami nawet skrajne. Przykładów nie trzeba szukać daleko - likwidowanie w Polsce po 1989 roku pomników związanych z ideologią komunistyczną czy też współczesne postawy społeczne wobec obiektów reprezentujących określony światopogląd świadczą o zdecydowanym oddziaływaniu symbolicznym tych obiektów na społeczeństwo. Celem stawiania pomników nie jest jednak wywoływanie napięć społecznych, jest nim zakomunikowanie pewnych wartości, ukazanie tego, że grupy osób (np. reprezentanci władzy) zaangażowane w postawienie monumentu w taki a w taki sposób pojmują rzeczywistość, że reprezentują takie a takie postawy, że tak a tak je należy postrzegać. Można więc powiedzieć, że pomniki „wytwarzają” wizerunki społeczne inicjatorów ich wzniesienia. Od kształtu tych wizerunków zależą reakcje społeczne. Ten punkt widzenia jest tutaj niezmiernie istotny.

Pomniki, jak sama nazwa wskazuje, kojarzone są z przywoływaniem pamięci o czymś. Może to być pamięć o postaciach, wydarzeniach, miejscach, symbolach, przedmiotach i wielu innych elementach ważnych dla większych lub mniejszych grup społecznych. Z punktu widzenia niniejszego opracowania interesujące będą jednak tylko te pomniki, które związane są z działalnością przedsiębiorstw, czyli szczególnego rodzaju organizacjami pojmowanymi ogólnie jako „różnorodne formy zorganizowanego działania ludzi” [Kożuch 2010: 20]. W rozumieniu autora niniejszego artykułu pomnik organizacji to wyeksponowany $\mathrm{i}$ jedyny $w$ swoim rodzaju obiekt przestrzenny o symbolicznym znaczeniu, związany z „życiem” organizacji. Pomnikami organizacji można nazwać wszystkie monumentalne obiekty odnoszące się bezpośrednio do kultury organizacyjnej i tożsamości organizacji, ale także pomniki powstałe w wyniku zaangażowania tej ostatniej, a odnoszące się do tożsamości innej grupy społecznej (np. mieszkańców danej miejscowości). Istnieją pomniki różnych typów organizacji: publicznych (np. pomnik Ludwika Rydygiera przed szpitalem w Toruniu), trzeciego sektora (np. pomnik Wikipedii w Słubicach) czy przedsiębiorstw. Jak jednak wspomniano, to pomniki przedsiębiorstw stanowią rdzeń niniejszego opracowania. Co więcej, wzięto pod uwagę wyłącznie te obiekty, w których stworzenie zaangażowane było przedsiębiorstwo. Istnieją bowiem pomniki nawiązujące do działalności przedsiębiorstw, które jednakże powstały wyłącznie w wyniku oddolnych inicjatyw społecznych lub działań organów publicznych (centralnych i lokalnych).

W nawiązaniu do tego, co wskazano w pierwszym akapicie artykułu - że poprzez pomniki „wytwarza” się wizerunek osób inicjujących jego powstanie - sformułowano pytanie badawcze: Jakie wizerunki przedsiębiorstw wytwarzają stawiane przez nie pomniki? Problem badawczy wpisuje się w obszar tematyczny zarządzania w kulturze. $Z$ jednej strony bowiem porusza się tu kwestie tworzenia wizerunku przedsiębiorstw, z drugiej mowa o pomnikach, czyli obiektach o potencjale kulturowym 
(społecznym) i kulturalnym (twórczym). Widoczny jest tu także rys zarządzania humanistycznego - zwłaszcza w związku z poruszaniem się w przestrzeni symboli i symbolizmu organizacyjnego [Turner 1986], czyli w ramach wykorzystywanego w naukach o zarządzaniu paradygmatu interpretatywno-symbolicznego [Kostera 2003: 16-17, Burrell, Morgan 2005, Sułkowski 2012: 116-117, Laberschek 2018: 32-34]. Zanim poruszy się kolejne wątki pracy, należy rozwikłać kwestie definicyjne. Jest to szczególnie ważne, bowiem w naukach o zarządzaniu sprawa tego, czym jest wizerunek, okazuje się dość skomplikowana. Oczywiście chodzi tutaj o wyjaśnienie, czym jest wizerunek organizacji (tutaj: przedsiębiorstwa), a nie produktu, marki [Kall, Kłeczek, Sagan 2006: 15] czy samego pomnika. Najogólniej można powiedzieć, cytując Mary Jo Hatch, że wizerunek organizacji (organizational image) to „wrażenie, jakie organizacja robi na innych” [Hatch 2002: 256]. „Wrażenie” może być czasami zastąpione „wyobrażeniem”, „skojarzeniem”, „odbiciem”, jednak za każdym razem chodzi tutaj o pewien niematerialny, nieprecyzyjny twór, który pojawia się w świadomości ludzi w odniesieniu do konkretnej organizacji. Ten twór powstaje $w$ wyniku komunikowania się organizacji $z$ otoczeniem $i$ „pod wpływem informacji [o organizacji - przyp. M.L.] z innych źródeł” [Budzyński 2008: 27]. Pomniki przedsiębiorstw można postrzegać jako formę komunikacji tych organizacji $z$ otoczeniem. Co prawda jest to rodzaj komunikacji nie wprost, symbolicznej, mimo wszystko jednak do niej dochodzi, a w związku z tym wizerunek przedsiębiorstwa może powstawać w jej wyniku. Dzięki badaniom osób wchodzących w komunikacyjną interakcję z pomnikiem można zatem poznać wytworzony z jego udziałem wizerunek przedsiębiorstwa.

Jest jeszcze jednak drugie rozumienie wizerunku organizacji. W Słowniku języka polskiego odnaleźć można definicję mówiącą, że wizerunek to „sposób, w jaki dana osoba lub rzecz jest postrzegana i przedstawiana” [Słownik języka polskiego... 2007: 1150 , „wizerunek”]. Wizerunek można zatem rozumieć nie tylko jako rodzaj „postrzegania” czegoś, ale również jako „sposób” „przedstawiania”, czyli prezentowania, ukazywania, komunikowania - dotyczy to również organizacji. Tę dwoistość dostrzegł Mats Alvesson, nazywając pierwszy wizerunek: „obrazem mentalnym” (sense image), a drugi „obrazem komunikowanym” (communicated image) [Alvesson 1990: 375]. To drugie ujęcie przybliża Alicja Waszkiewicz: „Rozumiany w ten sposób wizerunek jest komunikowanym znaczeniem «Ja-obiektu», jego atrybutami, niekoniecznie goszczącymi w umyśle odbiorcy. W tym przypadku wizerunek jest przekazem" [Waszkiewicz 2011:28]. W związku z tym można zatem badać wizerunki organizacji poprzez to, w jaki sposób owe organizacje komunikują się z otoczeniem. Owszem, jak wspomniano, pomniki są szczególnego rodzaju formą komunikacji przedsiębiorstw - komunikacji symbolicznej - ale podejmując się analizy tego, co pomniki przedstawiają oraz jakie jest znaczenie tych przedstawień, nakreślić można co prawda w pewnym sensie metaforyczny, ale jednakże głęboko interesujący wizerunek przedsiębiorstw. Takie kroki też powzięto. 


\section{Zarys metodologii}

By poznać wizerunki przedsiębiorstw wytwarzane (komunikowane) przy użyciu pomników, niezbędne było dysponowanie bazą pomników wraz z materiałami na ich temat. Autor niniejszego artykułu opracowuje taką bazę, wykorzystując potencjał wyszukiwarki Google; w czasie od marca do grudnia 2018 roku udało się uzyskać dane na temat ponad 80 pomników polskich przedsiębiorstw. Pozyskiwano informacje pochodzące $\mathrm{z}$ internetowych portali informacyjnych (najczęściej tych o lokalnym znaczeniu), zdigitalizowanych czasopism oraz książek na temat pomników i przedsiębiorstw, ze stron internetowych przedsiębiorstw, z cyfrowych wersji informatorów i wydawnictw zakładowych, $\mathrm{z}$ regionalnych zestawień pomników, $\mathrm{z}$ blogów i forów tematycznych; gromadzono również fotografie pomników.

Należy się wyjaśnienie, w jaki sposób identyfikowano pomniki w przestrzeni internetu. W pierwszej kolejności wpisywano w wyszukiwarkę frazę „pomnik przedsiębiorstwa”, a także jej podobne: „,pomnik zakładu”, ,pomnik fabryki”, „pomnik firmy”, „pomnik wytwórni”. W celu zwiększenia skuteczności poszukiwania wykorzystano udostępnione w serwisie Wikipedia.pl [Przemysł...] branżowe zestawienie przemysłu. Dzięki temu do wyszukiwarki wpisywano także hasła sprecyzowane według branż, np.: „pomnik elektrowni”, „pomnik huty”, „pomnik cukrowni”, ,pomnik wodociągów”, „pomnik zakładów chemicznych” czy „pomnik zakładów metalurgicznych”. Po wpisaniu odpowiedniej frazy do wyszukiwarki, wyszukiwano nie tylko interesujące treści, ale także fotografie. W tym celu korzystano zakładki „Grafika”. Pośród udostępnionych ilustracji identyfikowano te, które prezentowały pomniki; w następnej kolejności sprawdzano ich ewentualne powiązanie z przedsiębiorstwami.

Po odnalezieniu pomnika i powiązaniu go z przedsiębiorstwem, pogłębiano wiedzę o nim. Poszukiwano w internecie na przykład szczegółów o postaciach, obiektach lub wydarzeniach, do których pomnik się odwoływał. Pozyskiwano również wiedzę na temat twórców monumentów i materiałów, z jakich je wykonano. Interesujące też były informacje dotyczące historii przedsiębiorstw, zwłaszcza tych wątków, które bezpośrednio wiązały się z pomnikiem, np. kto wydawał decyzję o jego stworzeniu i wzniesieniu? W jakim celu? Przy jakiej okazji? Kto uczestniczył w jego odsłonięciu i jak wyglądała uroczystość?

Baza pomników i danych permanentnie powiększa się. Oczywiście sama w sobie jest wyłącznie swego rodzaju zapleczem badawczym, tematycznie określonym zestawem danych; jednakże jej potencjał ujawnia się, gdy w grę wchodzi rozwiązanie odpowiedniego problemu badawczego. Konkretny problem badawczy determinuje bowiem sposób wykorzystania danych z bazy.

W celu uzyskania odpowiedzi na postawione w niniejszym artykule pytanie badawcze - przypomnijmy: jakie wizerunki przedsiębiorstw wytwarzają stawiane przez nie pomniki? - w pierwszej kolejności odseparowano takie pomniki, które powiązane były z działalnością przedsiębiorstwa, a w których wzniesieniu nie brało 
ono udziału. W tym celu przeprowadzono analizę danych zastanych (desk research) [zob. Babbie 2006], materiałów, które wcześniej zgromadzono. Drugi etap pracy podzielono na dwie części, z których pierwsza miała charakter analityczno-opisowy, a druga interpretatywny. W pierwszej chodziło o to, by stwierdzić, co przedstawiają pomniki i z jakimi aspektami działalności przedsiębiorstwa powiązane jest to przedstawienie. Należało więc dotrzeć do bazy fotograficznej pomników i przeprowadzić ich analizę wizualną. Wykorzystano w tym celu metodę zaproponowaną przez Piotra Sztompkę, gdzie: „Przedmiotem [badania - przyp. M.L.] będzie (...) to, co sfotografowane" [Sztompka 2006: 8], przy czym fotografia przedstawia jeden z elementów życia społecznego: „kulturę” [ibidem: 42]. Podczas analizy wizualnej pomnika korzystano także $\mathrm{z}$ analizy danych zastanych - chodziło o odniesienie do tego, co pomnik przedstawia, historii przedsiębiorstwa oraz tego, czym się ono zajmuje. Jeśli np. pomnik przedstawiał postać związaną z przedsiębiorstwem, należało dowiedzieć się, kim ta postać jest i jaka była jej rola społeczna w organizacji. Po zrealizowaniu tej części okazało się, że to, co przedstawiają pomniki, czyli to, co wytwarza „komunikowane wizerunki” przedsiębiorstw, da się podzielić na dziewięć kategorii. Stwierdzono, że źródłem wizerunków mogą być: 1) trudne doświadczenia przedsiębiorstw; 2) pamiątki przedsiębiorstw; 3) wybitne jednostki przedsiębiorstw; 4) ludzka praca; 5) dokonania przedsiębiorstw; 6) znaki handlowe przedsiębiorstw; 7) zaangażowanie społeczne przedsiębiorstw; 8) zaangażowanie polityczne przedsiębiorstw; 9) metafizyczne wartości przedsiębiorstw. Kategorie te wykorzystano jako podtytuły części opisowej niniejszego opracowania. Każdą z nich oddzielnie omówiono, podając stosowne przykłady pomników.

Podczas omawiania wspomnianych kategorii, czyli tego, co stanowi „pomnikową" podstawę tworzenia wizerunków przedsiębiorstw, podjęto docelową próbę określenia i nazwania tych „komunikowanych wizerunków” (próbę tę zaprezentowano poniżej). W tym celu niezbędne okazało się wskazane wcześniej podejście interpretatywne. Wizerunków tych nie widać bowiem bezpośrednio, nie ujawniają się one w tkance pomnika, ale wynikają z subiektywnej, jednakże rzetelnie przeprowadzonej interpretacji wszystkich pomników i ich wzajemnej analizy porównawczej. Wizerunki są więc swego rodzaju interpretacjami i przypuszczeniami autora, nie wiadomo zatem, czy odpowiadają one rzeczywistym wizerunkom przedsiębiorstw powstałym wśród osób, które kojarzą te pomniki; poza tym wizerunki owe mogą także odbiegać od tych, które pojawią się w świadomości czytelników niniejszej pracy. Autor ma tego świadomość - wynika to jednak stąd, że pomniki są swego rodzaju „dziełem otwartym” [Eco 1973], w którego istotę niejako wpisana jest wielość interpretacji i wieloznaczność. 


\section{Wizerunki oparte na trudnych doświadezeniach przedsiębiorstw}

W życiu każdej organizacji mają miejsce takie sytuacje i zdarzenia, które nie pozostają bez wpływu na to, w jaki sposób organizacja działa w kolejnych latach - wydarzenia, które odciskają swego rodzaju trwały ślad, piętno. Ich znaczenie ma wymiar symboliczny - trwale wpisuje się w kulturę organizacji, a nierzadko także w kulturę lokalnej społeczności, w której przestrzeni organizacja funkcjonuje. Monumentalne uwiecznianie tego typu zdarzeń ma więc być swoistym wyrażeniem tego znaczenia, ale także ukazaniem organizacji dysponującej wyjątkowym i społecznie istotnym dziedzictwem kulturowym.

Uwiecznianie poprzez pomniki wydarzenia $\mathrm{z}$ historii polskich przedsiębiorstw często mają wymiar martyrologiczny. Wpisuje się to poniekąd w ogólnopolską narrację historyczną (również konstruowaną i utrwalaną przy użyciu pomników), która nierzadko odwołuje się do ludzkiego cierpienia. Wydawać się może, że poprzez pomniki przedsiębiorstwa podejmują próbę podzielenia się z otoczeniem bagażem własnych, trudnych, traumatycznych doświadczeń, przedstawienia bolesnego obrazu siebie i zachowania go w społecznej pamięci. Tym samym przedsiębiorstwa, które stereotypowo postrzegane są poprzez pryzmat ekonomicznych celów działalności, ukazują swój humanistyczny (ludzki) obraz. Wydaje się w związku z tym, że dzięki pomnikom przedsiębiorstwa w symboliczny sposób realizują to, do czego dążą naukowcy reprezentujący nurt zarządzania humanistycznego, w którym chodzi przede wszystkim o „poznanie i poprawę losu człowieka w organizacji” [Kociatkiewicz, Kostera 2013: 13]. Uzewnętrznianie trudnych zdarzeń z życia organizacji, zwłaszcza ich ludzkiej perspektywy, przyczynia się do ich lepszego poznania i zrozumienia, co z kolei może zapobiegać podobnym sytuacjom $\mathrm{w}$ przyszłości.

W niniejszym artykule nie ma miejsca, by dokładnie omówić i podać wszystkie przykłady pomników przedsiębiorstw o martyrologicznym znaczeniu, warto jednak zaprezentować kilka $\mathrm{z}$ nich, ale przede wszystkim wyodrębnić dwie ich charakterystyczne kategorie. Po pierwsze, są to pomniki poświęcone ofiarom wydarzeń, do których doszło z przyczyn innych niż bezpośrednio ludzkie. W 1971 roku w rafinerii w Czechowicach-Dziedzicach w wyniku uderzenia pioruna wybuchł pożar, w którym zginęło 37 osób, zarówno pracowników przedsiębiorstwa, jak i ludzi walczących z żywiołem (strażaków i żołnierzy). Nieopodal zakładu ufundowano pomnik poświęcony ofiarom tragedii. Z kolei w 2011 roku w Rudzie Śląskiej odsłonięto monument upamiętniający dwadzieścia ofiar wybuchu metanu, do którego doszło dwa lata wcześniej w Kopalni Węgla Kamiennego „Wujek Ruch Śląsk”. Po drugie, są to obiekty wzniesione dla uczczenia pamięci pracowników, którzy zginęli z rąk innych ludzi - chodzi tutaj o zabójstwa o charakterze politycznym. W 1981 roku w Poznaniu przy dawnej zajezdni tramwajowej odsłonięto pomnik pracowników komunikacji miejskiej - ofiar Poznańskiego Czerwca 1956 roku (pierwszego strajku 
generalnego w Polsce komunistycznej). Natomiast w 1980 roku przed bramą Stoczni Gdańskiej postawiono pomnik Poległych Stoczniowców 1970, ofiar protestów robotniczych i jednocześnie pracowników przedsiębiorstwa.

\section{Wizerunki oparte na pamiątkach przedsiębiorstw}

Inną kategorią monumentów przywołujących to, co minione i ważne dla organizacji, są pomniki przedmiotów, które w różnym zakresie wykorzystywane były w działalności przedsiębiorstw. Jak wskazuje Marek Krajewski, „ich [przedmiotów - przyp. M.L.] używanie nie sprowadza się do stosowania ich jako narzędzi, ale przenoszą one znaczenia i je chronią, (...) są funkcjonznakami, obiektami przejściowymi, (...) reprezentują tożsamości zbiorowe i indywidualne" [Krajewski 2005: 8]. Pomników-przedmiotów nie stawia się więc ze względu na ich użyteczność, ale dlatego, że są ważne dla grupy osób współtworzących daną organizację. Są ważne, bo odsyłają do wspólnych wspomnień. Dlatego też pomniki tego rodzaju traktować należy jak pamiątki organizacyjne - każdą bowiem pamiątkę pojmuje się „w kontekście czasu, przeszłości i pamięci" [Śnieżko 2013: 100]. Pamiątki organizacyjne nie są więc zwykłym artefaktem, ale poprzez odsyłanie do wspólnego dziedzictwa utrwalają wśród pracowników pamięć o organizacji.

Istnieją dwie możliwości wejścia w posiadanie pamiątki. Pamiątkę można otrzymać od kogoś (wówczas jest to upominek) lub też zatrzymać dla siebie wybrany przedmiot i traktować go jak własną pamiątkę [Banaszkiewicz 2011: 5]. Jedno i drugie podejście występuje w zarządzaniu organizacjami. Pierwsze charakterystyczne jest zwłaszcza dla działalności marketingowej - pamiątki dołącza się do produktów (np. zestaw Happy Meal w barach McDonald's) lub usług (choćby podczas wizyty dziecka u stomatologa). Pamiątki mają szczególne znaczenie na rynku doznań [Kostera, Śliwa 2012: 215]. Chodzi o to, by „klient wyszedł z czymś, co będzie mu się kojarzyć z przeżyciem” [Kostera 2012: 372], którego doświadczył, odwiedzając jakieś wyjątkowe miejsce (np. park rozrywki) lub biorąc udział w wydarzeniu (np. w koncercie).

Drugie podejście ma miejsce wówczas, kiedy to przedstawiciele organizacji zatrzymują wybrany przedmiot dla siebie jako pamiątkę. Z jednej strony może to być zdjęcie lub rysunek kogoś bliskiego, które pracownik przechowuje w bardziej lub mniej widocznym miejscu swojego stanowiska pracy. Z drugiej pamiątka może dotyczyć wszystkich pracowników i być bezpośrednio związana z samą organizacją. Taką rolę odgrywają urządzenia, pojazdy, produkty, wyposażenie i wiele innych, również drobnych przedmiotów, które nabrały sentymentalnej wartości. Z tego właśnie powodu zdarza się, że podobne przedmioty traktuje się w sposób szczególny: zabezpiecza i odnawia się, a niektóre z nich także publicznie eksponuje przed siedzibą organizacji w formie pomników. Publiczna prezentacja pamiątek organizacji 
to jednak nie tylko sposób utrwalania przeszłości organizacyjnej - postrzegać ją także należy jako próbę komunikowania i budowania wizerunku organizacji (tutaj przedsiębiorstwa), które dysponuje niezwykłą historią, taką, która warta jest monumentalnego przedstawienia. Można podać wiele przykładów pomników tego typu. W 2001 przed szybem „Pułaski” Kopalni Węgla Kamiennego „Wieczorek” w Katowicach postawiono dwa odrestaurowane wagony kolejki wąskotorowej „Balkan”. Do końca 1977 roku kolej dowoziła pracowników do kopalni. Z kolei 2015 roku przed bramą warszawskiej Huty ArcelorMittal postawiono pomnik hutniczego urządzenia - walcarki. O jej sentymentalnej wartości wypowiadał się inicjator pomnika, prezes przedsiębiorstwa Marek Kempa:

Postanowiłem, że trzeba zachować pamiątkę, która stanie na zawsze przed bramą Huty, by przypominać mieszkańcom Bielan historię wielu pokoleń pracowników Huty Warszawa. Ta klatka walcownicza produkowała wyroby stalowe, dając pracę i szansę na godne życie wielu tysiącom ludzi. Mamy do dziś w hucie osoby, które są hutnikami już w 3 pokoleniu. Ten pomnik to symbol ich pracy [Odsłonięcie hutniczego pomnika...].

Jedną z najbardziej oryginalnych pamiątek jest obiekt ustawiony w latach 70 . XX wieku przed siedzibą Kopalni Węgla Brunatnego „Turów” w Bogatyni (fot. 1). To w zasadzie pomnik przyrody, jest to bowiem skamieniałe drzewo iglaste Taxodioxylon gypsaceum. Ów pomnik należy traktować jako podwójną pamiątkę: upamiętnia zdarzenie wydobycia paleobotanicznego skarbu, ale także okres sprzed ok. $18 \mathrm{mln}$ lat, kiedy na terenie dzisiejszej Polski panował cieplejszy i bardziej wilgotny klimat.

\section{Wizerunki oparte na wybitnych jednostkach przedsiębiorstw}

W każdej społeczności pojawiają się osoby, które w jakiś szczególny sposób wyróżniają się, które są swego rodzaju wzorem dla innych, i które w związku z tym są ważne dla tej społeczności, a zatem także godne zapamiętania. $Z$ tego też powodu stawia się im często pomniki. Nie inaczej jest w przypadku organizacji, w tym przedsiębiorstw. Są pomniki poświęcone ich ojcom założycielom. Znaczenie takich osób dla przedsiębiorstw, a zwłaszcza dla ich tożsamości, jest bezdyskusyjne. Przenoszona w postaci opowieści wiedza o ojcach założycielach utrwala obraz organizacji w świadomości społecznej. Wiele osób kojarzy przecież postaci Steve’a Jobsa, Billa Gatesa i Elona Muska z powołanymi przez nich firmami: Apple, Microsoftem i Teslą. Jednakże pamięć o ojcach założycielach utrwala się nie tylko w społecznym otoczeniu przedsiębiorstwa - obecna jest także w społecznej tkance samej organizacji i często wpływa na jej funkcjonowanie; słyszy się np.: „Wielu decyzjom w dzisiejszej Walt Disney Company towarzyszy pytanie: «Co Walt zrobiłby w takiej sytuacji?»” [Griffin 1996: 180]. To właśnie swego rodzaju siła symbolicznego oddziaływania ojców założycieli 


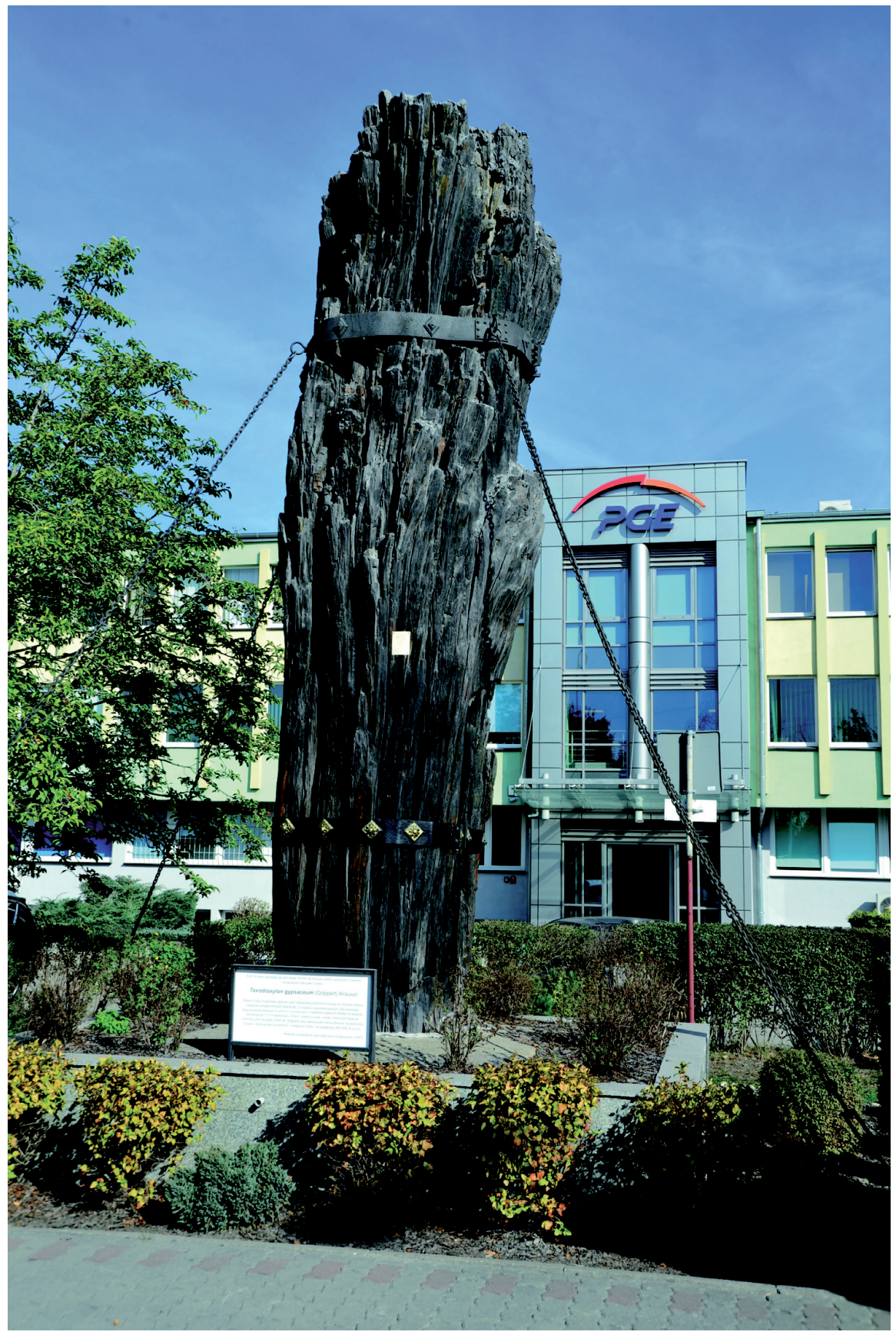

Fot. 1. Pomnik przyrody przed wejściem do siedziby Kopalni Węgla Brunatnego „Turów” w Bogatyni. Źródło: z zasobów i dzięki uprzejmości Kopalni Węgla Brunatnego „Turów” w Bogatyni 
na przedsiębiorstwo stoi u źródeł stawiania tym osobom pomników. W Bóbrce niedaleko Gorlic w 1982 roku na terenie czynnej do dzisiaj Kopalni Ropy Naftowej wzniesiono pomnik popiersie Ignacego Łukasiewicza, jednego ze współzałożycieli przedsiębiorstwa, natomiast w 2012 roku przed willą dla dyrektorów Zakładów Azotowych w Tarnowie-Mościcach odsłonięto popiersie Ignacego Mościckiego, na którego wniosek w 1927 roku rozpoczęto budowę przedsiębiorstwa.

W tym samym miejscu postawiono też inny obiekt, popiersie Eugeniusza Kwiatkowskiego, dyrektora zakładów w latach 1931-1935. To jeden z wielu przykładów pomników przedsiębiorstw poświęconych osobom piastującym kierownicze stanowiska - wybitnym menedżerom. Innym obiektem tego typu jest monument Antoniego Thuma, dyrektora i właściciela Browarów Grodziskich SA w Grodzisku Wielkopolskim, z 2016 roku. Prowadzony przez niego przed II wojną światową zakład osiągał nadspodziewanie dobre wyniki, a sam Thum utrzymywał bardzo dobre relacje z pracownikami i lokalną społecznością miasta.

Do trzeciej kategorii należy zaliczyć pomniki stawiane wyjątkowym pracownikom. Pomniki takie nie muszą być bezpośrednio związane $\mathrm{z}$ ich pracą wykonywaną w ramach organizacji. Przed budynkiem Miejskich Wodociągów i Oczyszczalni w Grudziądzu postawiono pomnik Bronisława Malinowskiego (fot. 2), pracownika zakładu, ale jednocześnie biegacza i mistrza olimpijskiego.

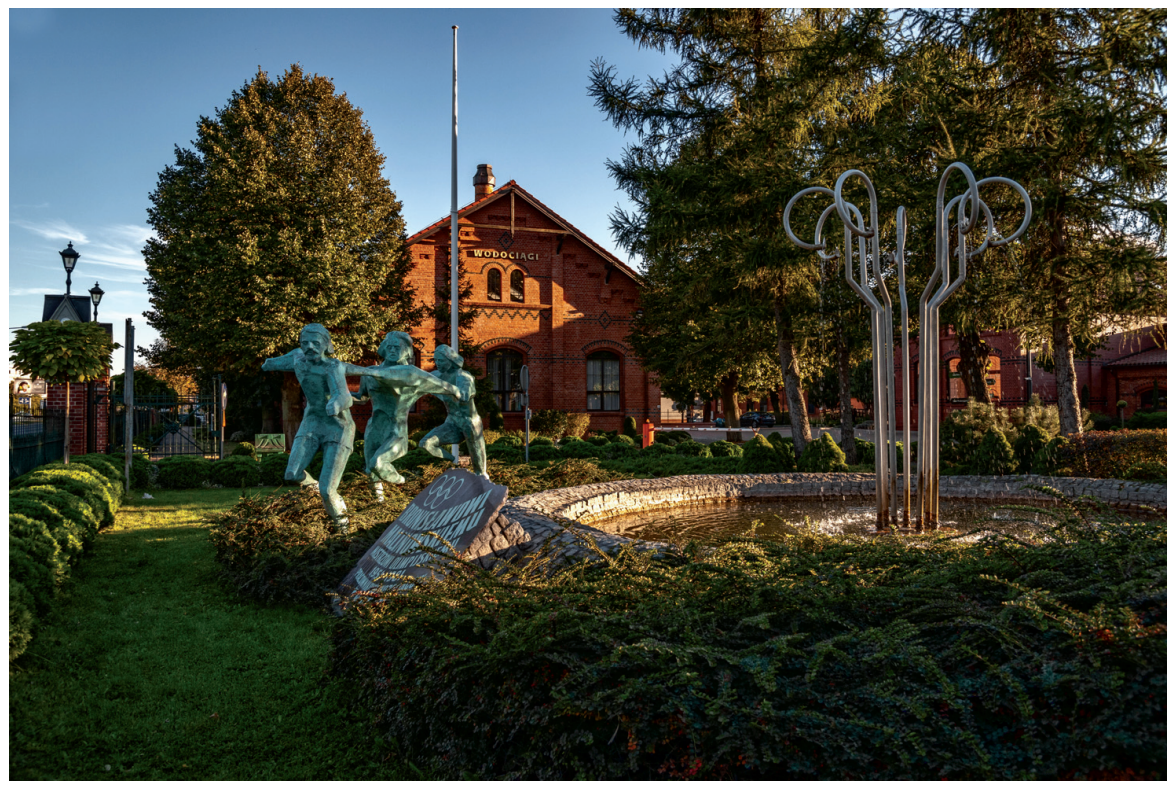

Fot. 2. Pomnik Bronisława Malinowskiego i uprawiających biegi pracowników Miejskich Wodociągów i Oczyszczalni w Grudziądzu.

Autor rzeźby: Ryszard Kaczor

Fot. Lesław Domowicz.

Źródło: z zasobów i dzięki uprzejmości Miejskich Wodociągów i Oczyszczalni w Grudziądzu 
Warto zwrócić uwagę, że dzięki tego typu obiektom przedsiębiorstwa starają się ukazać siebie jako dbające o swoje dziedzictwo i utrwalające pamięć o sobie. Budują obraz siebie jako organizacji, dla których pamięć o własnej przeszłości ma niebagatelne znaczenie. Tego rodzaju pamięć należy postrzegać jako istotną część kultury organizacyjnej przedsiębiorstwa, a czasami nawet jej fundament. $Z$ drugiej strony, poprzez to, że współtworzyli ją wyjątkowi ludzie, starają się dowieść swojej unikatowości.

\section{Wizerunki oparte na ludzkiej pracy}

Istnieje też inna kategoria pomników przedsiębiorstw przedstawiających ludzkie wizerunki, z tym że obiekty te nie przedstawiają żadnej konkretnej osoby - są to osoby anonimowe, nieistniejące, związane jednak z jakimś konkretnym zawodem, ludzie pracy. W pomnikach doszukać się więc można humanistycznych obrazów zarządzania przedsiębiorstwami, które podkreślają wagę i istotę ludzkiej pracy oraz kulturowego jej znaczenia. Anonimowe postaci robotników mogą mieć więc wymiar archetypiczny - mogą choćby odsyłać do archetypu ciężkiej lub odpowiedzialnej pracy $^{1}$. Zresztą praca sama w sobie jest również archetypem. Hezjod, grecki poeta, jako pierwszy podjąl próbę analizy pracy ludzkiej. Doszukał się w niej archetypicznego znaczenia, twierdząc, jak pisze Tomáš Sedláček w Ekonomii dobra i zła, że „praca jest losem człowieka, jego przywilejem i źródłem wszelkiego dobra. Ci, co nie pracują, zasługują wyłącznie na pogardę" [Sedláček 2012: 110].

W polskich warunkach najczęściej występują pomniki kolejarzy, górników oraz hutników, które lokalizuje się przed siedzibami przedsiębiorstw (szybami górniczymi, bramami wejściowymi, stacjami kolejowymi) lub na ich terenie. Związek człowieka z zawodem można rozpoznać nie tylko poprzez bliskość organizacji, ale też przez charakterystyczne, wkomponowane w strukturę pomnika artefakty atrybuty (np. uniform wraz z kaskiem, kilof oraz latarkę w przypadku pomnika górnika sprzed Kopalni Węgla Kamiennego w Rudzie Śląskiej czy żaroodporny uniform wraz z nakryciem głowy, łyżkę odlewniczą oraz koło zębate, jeśli chodzi o obiekt hutnika odlewnika Odlewni „Świdnica”) lub poprzez artefakty i wykonywaną czynność (pomnik Huty w Ujściu w województwie wielkopolskim prezentuje hutnika w trakcie czynności „dmuchania” szkła - nadawania kształtu hutniczym wyrobom).

Przez publiczną ekspozycję monumentu człowieka z przedmiotami reprezentującymi konkretny zawód zwraca się uwagę na etos, czyli zestaw charakterystycznych cech, wartości i cnót związanych z tym zawodem. Komunikowanymi przez pomnik,

${ }^{1}$ Badacze nauk o zarządzaniu identyfikują archetypy w różnych przejawach pracy. Dariusz Jemielniak w książce Praca oparta na wiedzy. Praca w przedsiębiorstwach wiedzy na przykładzie organizacji high-tech wspominał np. o archetypie pracy biurowej [Jemielniak 2008: 130]. 
a charakterystycznymi dla kolejarzy wartościami będą więc odpowiedzialność, porządek, skrupulatność, dokładność, szacunek i wiele innych. Etos pracy hutników i górników opiera się natomiast na wysiłku, poświęceniu, narażaniu zdrowia i życia, współpracy itd. W każdym przypadku liczą się również wartości kulturowe, w tym status danego zawodu w społeczeństwie. W przypadku górników dochodzi jeszcze społeczny aspekt regionalizmu. Etos górnika jest sprzężony z kulturą regionalną (zwłaszcza górnośląską). Interesującym tego przykładem jest postawiony w 2009 roku pomnik przed Kopalnią Węgla Kamiennego „Bolesław Śmiały” w Łaziskach Górnych, przedstawiający postać górnika wraz z jego atrybutami, do którego dodatkowo dołączono tablicę z poniższą informacją:

W Łaziskach fedruje sie wongel łod dwustu trzydziestu lot. A piyrszo gruba [kopalnia - przyp. M.L.] w naszym mieście nosiła miano: „Śzczynście Henryka”. Tukyj łobejżeć se możecie chłopca w koszuli, w galotach i gumniokach, kiery w kacholu z lampą idzie na szychta. W rynce trzimo pyrlik. Pod galotami (czego niy widać) mo łobleczone spodnioki a szłapy mo łowinynte onucami. Spoziyro na swoja gruba kiero terozki nazywo sie „Bolesław Śmiały”.

Kopalnia, przed której siedzibą postawiono powyższy monument, to zatem miejsce pracy (tutaj przecież górnik ,idzie na szychta”), której etos wynika z lokalnej kultury, w tym języka, tradycji, historii oraz specyficznej symboliki. Jest więc miejscem pracy szczególnego rodzaju, gdyż pracują tu zarazem górnicy i Ślązacy. Można powiedzieć, że występuje tutaj rodzaj sprzężenia zwrotnego pomiędzy kulturą organizacyjną kopalni a kulturą lokalnej społeczności i obie wzajemnie się dopełniają, jedna czerpie $\mathrm{z}$ drugiej. Taki obraz kopalni ukryty jest więc w zaprezentowanym pomniku.

\section{Wizerunki oparte na dokonaniach przedsiębiorstw}

W literaturze poświęconej zarządzaniu marketingowemu sporo miejsca w ostatnim czasie poświęca się marketingowi dokonań, który „wymaga rozumienia istoty korzyści finansowych i niefinansowych, jakie działania marketingowe przynoszą biznesowi i społeczeństwu" [Kotler, Keller 2018: 24]. Coraz częściej zauważa się i podkreśla znaczenie tego, że organizacje odciskają swoje piętno na społeczeństwie nie tylko ze względu na to, czym bezpośrednio się zajmują. Trzeba bowiem zwrócić uwagę, że „skutki działań marketingowych dotykają nie tylko firmę i klientów, lecz również społeczeństwo jako całość" [ibidem: 26]. Chodzi tutaj o to, że efekt działania organizacji nie jest zwykłym odzwierciedleniem liczby sprzedanych produktów, ale

${ }^{2}$ Cytat pochodzi z tablicy zamieszczonej na pomniku górnika znajdującego się przy ul. Świętej Barbary w Łaziskach Górnych. 
uwidacznia się także ze względu na inne aspekty, których wartość jest często niepoliczalna. Organizacja jest bowiem powiązana $\mathrm{z}$ otoczeniem relacjami nie tylko ekonomicznymi, ale też kulturowymi. Rozpoznawalnych marek, niepowtarzalnych wizerunków czy też odpowiedniej reputacji organizacji nie da się zatem uzyskać, koncentrując się wyłącznie na realizacji podstawowego celu organizacji. Niezbędne stają się też innego rodzaju działania - zwłaszcza takie, które są istotne ze społecznego punktu widzenia. Organizacja podejmująca tego typu działania uzyskuje dodatkowy kapitał - status społeczny.

Status społeczny zależy do tego, jaki jest obraz organizacji w otoczeniu, czyli jaki jest jej wizerunek. Organizacje mogą więc dążyć do tego, by to, czym się zajmują było również ważne dla społeczeństwa, by produkty stawały się czymś więcej niż zwykłymi towarami, by nabierały znaczenia kulturowego, by sukcesy organizacji stawały się sukcesami społecznymi. Istnieją więc takie pomniki przedsiębiorstw, które odnoszą się do osiągnięć i sukcesów - czyli dokonań przedsiębiorstw. Ponieważ pomniki łączą świat wewnętrzny przedsiębiorstw $\mathrm{z}$ otoczeniem, to dokonania przedsiębiorstw stają się po części dokonaniami społeczności, w której te ostatnie funkcjonują. Pomniki mogą zatem tworzyć w świadomości odbiorców wizerunek przedsiębiorstwa stanowiącego integralną część otoczenia społecznego.

W 1983 roku w niewielkiej miejscowości Biesiekierz w województwie zachodniopomorskim, nieopodal Stacji Hodowli Roślin, odsłonięto dziewięciometrowy pomnik ziemniaka. Inicjatorem postawienia obiektu był ówczesny dyrektor zakładu Mariusz Roeder. Chodziło o to, by upamiętnić szczególne osiągnięcie - wyhodowanie przez przedsiębiorstwo dziewięciu nieistniejących wcześniej odmian ziemniaka. O społecznym znaczeniu pomnika (jak i związanej z nim historii) świadczy to, że obiekt stał się głównym motywem graficznym herbu miejscowości, a sam Biesiekierz nazwano „stolicą ziemniaka”.

O podobnym znaczeniu społecznym można mówić w odniesieniu do innych pomników przedsiębiorstw. W 1982 roku w miejscowości Osowa Sień (woj. lubuskie) wzniesiono pomnik Ilona, byka z pobliskiego Państwowego Ośrodka Hodowli Zarodowej. Motywem postawienia monumentu były wyjątkowe zdolności reprodukcyjne zwierzęcia. Opowieść o nim, będąca początkowo historią należącą do samego przedsiębiorstwa, stała się częścią tożsamości lokalnej społeczności. Dokonało się to również - a może zwłaszcza - za sprawą pomnika. Są też inne pomniki odwołujące się do osiągnięć i dokonań przedsiębiorstw. Choćby pomnik sprzed firmy Michelin Polska SA w Olsztynie przedstawiający produkowaną w zakładach największą w skali światowej oponę. W świętokrzyskim Stąporkowie stoi z kolei trzymetrowy monument grzejnika, popularnego żeliwnego kaloryfera używanego w czasach PRL (fot. 3). Miejscowa odlewnia żeliwa była monopolistą - wyprodukowała ponad

${ }^{3}$ Określenie to odnaleźć można na stronie poświęconej Biesiekierzowi w serwisie Wikipedia: https://pl.wikipedia.org/wiki/Biesiekierz [odczyt: 27 grudnia 2018]. 
90\% grzejników używanych w komunistycznej Polsce. Pomimo że przedsiębiorstwo już nie istnieje, dla lokalnej społeczności pomnik-produkt ma w dalszym ciągu szczególne znaczenie.

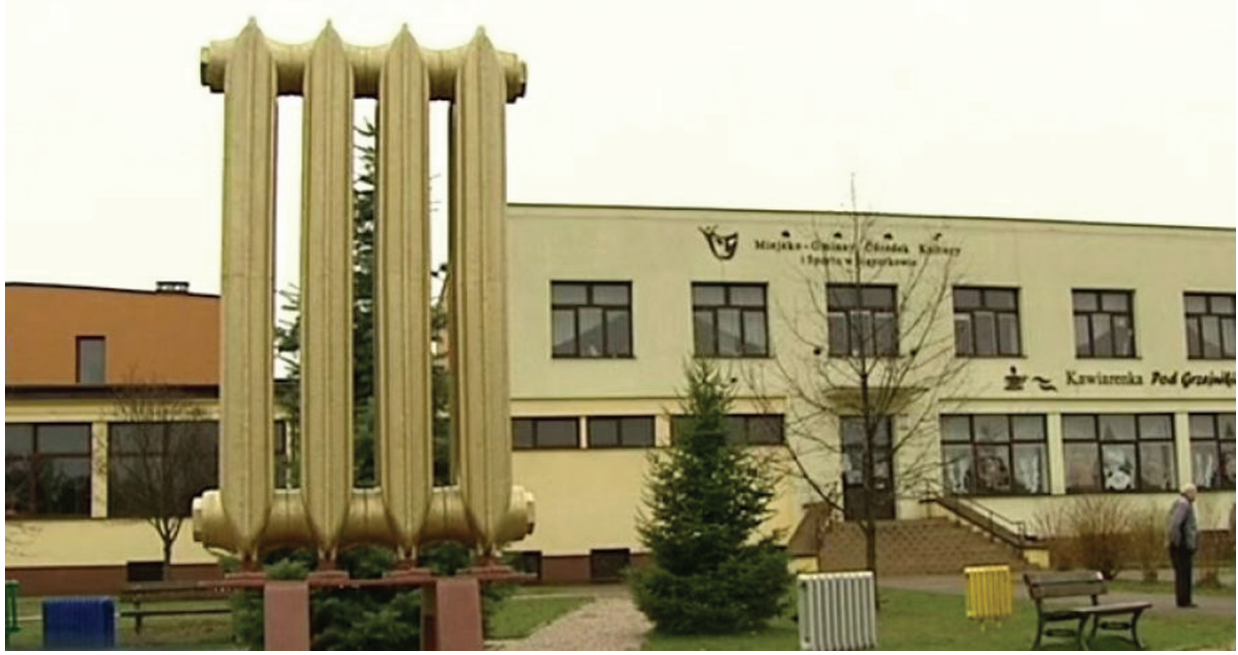

Fot. 3. Pomnik grzejnika - produktu Odlewni Żeliwa Stąporków.

Źródło: z zasobów i dzięki uprzejmości Miejsko-Gminnego Ośrodka Kultury w Stąporkowie

\section{Wizerunki oparte na znakach handlowych przedsiębiorstw}

Zdaniem Bernda Schmitta i Alexa Simonsona, autorów książki Estetyka w marketingu. Strategiczne zarządzanie markami, tożsamością i wizerunkiem firmy:

Podobnie jak inne organizacje firmy przemysłowe tworzą wśród odbiorców swój image nie tylko poprzez „surowe” produkty, ale także dzięki opakowaniu, prospektom, wyglądom samochodów dostawczych czy reklamie handlowej itp. [Schmitt, Simonson 1999: 36].

Badacze zwracają uwagę na to, jak istotną rolę w tworzenia wizerunku (image) organizacji odgrywają elementy identyfikacji wizualnej. Jednym z najważniejszych jej komponentów (o którym jednak nie wspomniano w powyższym cytacie) są firmowe znaki handlowe zwane logotypami. Według niektórych specjalistów logotypy należą do podstawowych narzędzi zarządzania wizerunkiem organizacji [Kotler 1994, Macalik 2013]. 
Schmitt i Simonson podkreślają, że odpowiednio zaprojektowane komponenty identyfikacji wizualnej organizacji pozwalają postrzegać ją jako organizację o wysokiej jakości [Schmitt, Simonson 1999: 36]. Być może jednak oprócz wizerunku przedsiębiorstwa wysokiej jakości tworzą się jeszcze inne jego obrazy. Logotypy są śladami pozostawionymi przez organizację $\mathrm{w}$ otoczeniu; sama ich obecność może tworzyć wśród odbiorców obraz organizacji ważnej i liczącej się. Tym bardziej jeśli logotypy stają się motywem pomników organizacji - pomników bowiem nie stawia się przypadkowo, istotne jest też to, co przedstawiają.

Logotyp przedsiębiorstwa może przybrać całkowicie „pomnikową” postać dotyczy to choćby obiektu Przedsiębiorstwa Połowów Dalekomorskich i Usług Rybackich „Odra” w Świnoujściu. Dla mieszkańców miasta ma on tak dużą wartość symboliczną, że w 2015 roku, już po likwidacji przedsiębiorstwa, odrestaurowano go i pozostawiono na pamiątkę. W wielkopolskich Pudliszkach w 2016 roku nieopodal tamtejszego przedsiębiorstwa zajmującego się przetwórstwem owocowo-warzywnym również stanął pomnik logotypu. Interesujące jest jednak to, że nie jest to aktualny znak firmowy, a historyczny - z 1928 roku. Charakterystycznym elementem tego logotypu była wierzba z gruszkami. Symbol ten odnosił się do dziejów powstania zakładu w 1920 roku; sceptycznie nastawiona społeczność lokalna stwierdziła, że prędzej wyrosną gruszki na wierzbie niż powstanie w tym miejscu solidne przedsiębiorstwo [Miał wiedzę, wizję i odwagę...]. Pomnik Pudliszek może wytwarzać dodatkowy wizerunek organizacji - jako dbającej o własne dziedzictwo kulturowe. Podobnie jest w przypadku pomników-pamiątek

Są też pomniki, gdzie elementy logotypu są motywem przewodnim pomnika, on sam nie jest jednak idealnym odwzorowaniem znaku graficznego. Dotyczy to choćby monumentu, również nieistniejącej już organizacji - Kombinatu Przemysłowo-Rolnego Igloopol w Dębicy.

W pozostałych przypadkach pomniki stanowią artystyczne przedstawienie logotypu, w mniejszym lub większym stopniu do niego nawiązującym. Tak jest w przypadku obiektu Zakładów Chemicznych Anser w Wiskitkach (woj. mazowieckie) prezentującego ptaki w locie, pomnika renifera Dolnośląskich Zakładów Białoskórniczych-Rękawniczych „Renifer” w Świdnicy, żubra ustawionego przed główną siedzibą Banku Pekao SA w Warszawie oraz postaci Światowita Myszkowskiej Fabryki Naczyń Emaliowanych „Światowit” (pomnik tej ostatniej organizacji znajduje się obecnie na terenie Częstochowy).

Warto w tym miejscu podkreślić też to, że niektóre z pomników przedsiębiorstw, zapewne ze względu na ich wartość symboliczną, same stały się motywem graficznym logotypów. Stało się tak w przypadku wspomnianych już wcześniej monumentów: byka Ilona przy Hodowli Zwierząt Zarodowych Osowa Sień oraz hutnika Odlewni "Świdnica”. 


\section{Wizerunki oparte na zaangảzowaniu spolecznym przedsiębiorstw}

Ewa Filipp proponuje, by na społeczną odpowiedzialność biznesu spoglądać z trzech punktów widzenia: 1) jest to „strategia zarządzania i rozwoju firmy, budowana na gruncie wartości", biorących pod uwagę oczekiwania istotnych interesariuszy, np. klientów, dostawców, dystrybutorów; 2) to także „umiejętność prowadzenia przedsiębiorstwa", kładąca nacisk na podnoszenie kapitału społecznego, np. rozwój czytelnictwa, wzmacnianie postaw prozdrowotnych; 3 ) to wreszcie odpowiednie (w tym partnerskie) podejście do interesariuszy - osób i organizacji, z którymi utrzymuje się relacje [Filipp 2012: 97].

Przedsiębiorstwa, które stwarzają możliwość rozwoju artystycznego społeczeństwa również należy zaliczyć do kategorii zaangażowanych, czyli odpowiedzialnych społecznie. Najczęstszą formą jest mecenat i sponsoring: przedsiębiorstwa mogą przeznaczać środki na nagrody i stypendia dla twórców, mogą też finansować wydarzenia lub działalność instytucji artystycznych. Istnieje również inny rodzaj pomocy - udostępnienie artystom materiałów, narzędzi lub miejsca do pracy. W przypadku artystów z kręgu sztuk pięknych przedsiębiorstwa mogą dostarczać materiały, z których dzieła sztuki są wykonywane (kamień, beton, stal itd.) lub przestrzeń ( $w$ tym hal produkcyjnych), gdzie obiekty artystyczne mogą powstawać i być eksponowane. Wiele przedsiębiorstw pomagało i pomaga w ten sposób artystom.

Najczęściej podkreśla się, że społeczna odpowiedzialność biznesu wiąże się z rozwojem demokracji [Filek 2006] oraz jednym z jej przejawów - społeczeństwa obywatelskiego [Rok 2004]. Spostrzeżenie to jest jednak nie do końca prawdziwe. Być może skala zaangażowania społecznego współczesnych przedsiębiorstw jest większa (być może, bo problem ten nie jest zbadany), jednak te, które funkcjonowały w okresie peerelu również podejmowały takie kroki. Przykładem mogą być przedsiębiorstwa, które podejmowały współpracę z artystami tworzącymi pomniki. Część z tych obiektów pozostawiono na terenie lub przed siedzibą organizacji.

Efektem współpracy artysty z przedsiębiorstwem jest pomnik Skrzydła morza z 1973 roku autorstwa Anny Szalast. Pomnik do dzisiaj stoi na terenie Bydgoszczy, w okolicach przedsiębiorstwa Famor, które dostarczyło artystce materiał. W powstawaniu obiektu brali też udział pracownicy Famoru. Z kolei w Warszawie przed jednym z budynków dzisiejszej Huty ArcelorMittal stoi wykonany w 1976 roku przez Teresę Brzóskiewicz pomnik Hymn Warszawianki, który powstał w ramach warsztatów artystycznych organizowanych przez przedsiębiorstwo.

Dużych przedsięwzięć artystycznych, którym patronowały lub które bezpośrednio organizowały komunistyczne przedsiębiorstwa, odnotować można zresztą więcej. Pierwszym takim wydarzeniem było Biennale Form Przestrzennych w Elblągu, którego pierwsza odsłona odbyła się w 1965 roku. Sponsorem i organizatorem były Zakłady Mechaniczne Zamech. Warto też wspomnieć o warszawskim Biennale Rzeźby w Metalu z 1968 roku. Swoją pomoc w jego organizacji zaoferowało wówczas 
ponad dwadzieścia przedsiębiorstw, a patronat nad całością objęły Zakłady Radiowe im. Marcina Kasprzaka. Każde z tych wydarzeń - zarówno wszystkie edycje elbląskiego, jak i warszawskie biennale - zaowocowało powstaniem kilkudziesięciu rzeźb-pomników.

Obiekty, których powstanie jest efektem zaangażowania społecznego przedsiębiorstwa mogą więc wytwarzać w świadomości odbiorców specyficzny jego obraz. $\mathrm{Z}$ jednej strony z pewnością organizacji odpowiedzialnej społecznie, z drugiej, jak w przypadku pomników prezentujących dokonania przedsiębiorstw, organizacji będącej integralną częścią otoczenia społecznego, instytucją społeczną, a nie odrębnym organizmem kierującym się własnym interesem.

\section{Wizerunki oparte na zaangażowaniu politycznym przedsiębiorstw}

Teorie zarządzania (np. menedżeryzmu [Kostera, Śliwa 2010: 297; Oleksyn 2013: 159]) są swoistego rodzaju ideologiami [Sułkowski 2016], gdyż aranżują życie organizacji. Tworzą wewnętrzny system wartości, poglądów, postaw, co przekłada się, na to, jak organizacja działa: jaki jest jej język, jak wygląda jej struktura organizacyjna, jak sprawowana jest władza, jaką przyjęto strategię działania itd. Organizacje nie są jednak wyłącznie narażone na wpływ ideologii dotyczących zarządzania. Istnieją również inne ideologie, często o szerokim znaczeniu społecznym, które mają wpływ na funkcjonowanie organizacji. Organizacje się im poddają lub bronią się przed ich wpływem. Często są to ideologie polityczne, czyli aplikowane przez aparat władzy gotowe zestawy poglądów, do których podległe tej władzy podmioty (w tym organizacje) muszą się ustosunkować - przyjąć je lub odrzucić.

W czasach polski komunistycznej odrzucanie przez organizacje ideologii narzucanej przez władzę było w zasadzie niemożliwe. Odpowiednie komórki władzy prowadziły skuteczne zabiegi wkomponowywania założeń państwowej ideologii do kultury organizacyjnej przedsiębiorstw. Odbywało się to w sposób symboliczny, np. poprzez zastosowanie odpowiednich nazw („22 Lipca” zamiast „Wedel”), organizację rytuałów (zakładowe pochody pierwszomajowe), ale też stawianie pomników. W tym sensie pomniki „zdradzają” reprezentowaną przez przedsiębiorstwo ideologię.

Stawiane przed bramami przedsiębiorstw pomniki ideologiczne zazwyczaj przedstawiały postaci symbole komunizmu. Jedną z nich był Włodzimierz Ilicz Lenin. Jego popiersie wzniesiono przed Zakładami Metalurgicznymi w Skawinie, jak też przed wejściem na teren krakowskiego kombinatu - Huty im. Lenina (oczywiście nie chodzi tutaj o inny pomnik - monumentalną postać Lenina z alei Róż w Nowej Hucie). Z kolei w Warszawie przed Zakładami Mechanicznymi przy ul. Fort Wola 22 wzniesiono pomnik Marcelego Nowotki, przy ul. Kasprzaka przed Zakładami Radiowymi odsłonięto pomnik Marcina Kasprzaka, natomiast przed warszawskimi zakładami Bumar-Waryński przy ul. Kolejowej postawiono popiersie 
Ludwika Waryńskiego. Z kolei w Tarnowie-Mościcach przed Zakładami Azotowymi wzniesiono postument Feliksa Dzierżyńskiego, a we Włocławku przed Zakładami Celulozowo-Papierniczymi pomnik Juliana Marchlewskiego.

Pomimo że w obecnej sytuacji społeczno-gospodarczej żadne przedsiębiorstwo nie poddawane jest bezpośredniej indoktrynacji ze strony państwa, pojawiają się pomniki wskazujące na wzajemną zależność. Przykład tego typu odnaleźć można w Jaworznie - w 2017 roku na terenie tamtejszej Koksowni „Przyjaźń” odsłonięto obelisk odwołujący się do wizyty prezydenta Lecha Kaczyńskiego na terenie zakładu w 2005 roku. Przykład ten świadczy o tym, że ideologia państwowa oddziałuje na organizacje również obecnie.

Pomniki wznoszone w nawiązaniu do ideologii państwowej tworzą wizerunek niesamodzielnego (zależnego) przedsiębiorstwa - organizacji, która znajduje się w polu oddziaływania sił mających swoje źródło poza nią. Kreują również obrazy przedsiębiorstw nakierowanych na inne cele niż te, które wynikają bezpośrednio z profilu ich działalności; mogą być zatem postrzegane jako koniunkturalne.

\section{Wizerunki oparte na metafizycznej symbolice przedsiębiorstw}

Ideologia rozumiana jako wspólny dla danej grupy społecznej zestaw idei i poglądów może mieć także wymiar religijny. Religia wskazuje bowiem grupie, jak myśleć, jakie przyjąć postawy, jak zachowywać się wobec zjawisk i problemów, z którymi grupa może się zetknąć. W odróżnieniu od ideologii państwowej świeckiej (chodzi o ideologię państw nowoczesnych: demokratycznych i komunistycznych) religia ma podstawy transcendentalne, metafizyczne. To znaczy, iż odwołuje się ona do tego, czego nie da się racjonalnie wytłumaczyć - ludzkie możliwości, w tym język, są zbyt skromne, aby poznać sens istnienia. Dlatego pozostaje wiara, wiara w to, co jest źródłem i fundamentem wszystkiego, co istnieje. Wiara pozwala uniknąć niepewności, dając metafizyczne wyjaśnienie temu, co niezrozumiałe, nietypowe czy niebezpieczne.

Istnieją więc pomniki przedsiębiorstw odwołujące się do spraw metafizycznych. Pomnikowe postaci, a właściwie przypisywane im symboliczne znaczenia, dają organizacji transcendentalne oparcie, są zabezpieczeniem przed przyszłymi problemami, których nie da się przewidzieć. W taki przecież sposób spoglądać można na monumenty świętych Kościoła katolickiego, wznoszone przez różnego rodzaju przedsiębiorstwa. Przykładów jest wiele - choćby pomnik Świętego Krzysztofa wzniesiony w 1990 roku przez Przedsiębiorstwo Komunikacji Samochodowej w Turku. W 2013 roku, podczas zmiany lokalizacji monumentu, jego znaczenie podkreślał prezes organizacji: „Święty Krzysztof przenosił ludzi przez rzekę. Dzisiaj trochę odwrotnie jego przeniesiono na nowe miejsce, aby dalej patronował całej załodze PKS-u" [Patron kierowców w nowym miejscu...]. Podobne patronująco-opiekuńcze znaczenie mają wizerunki świętych wznoszone przed innymi przedsiębiorstwami: 
Świętej Katarzyny, patronki kolejarzy (Zakłady Naprawcze Taboru Kolejowego w Radomiu i w Opolu, PKP Cargo w Jaśle), Świętego Floriana, patrona hutników (Huta Miedzi Głogów, Huty Stalowa Wola) czy Świętej Kingi, patronki górników solnych (Kopalnia Soli w Wieliczce).

Nie tylko pomniki związane z Kościołem rzymskokatolickim mają metafizyczny wymiar. Inne, odwołujące się do odmiennych wierzeń, także będą miały takie znaczenie. W tym miejscu trzeba wspomnieć znów o pomniku Światowita, który prawdopodobnie w 1989 roku ${ }^{4}$ wzniesiono przed Myszkowską Fabryką Naczyń Emaliowanych „Światowit”. Postać ta, występująca też pod innymi nazwami: Świętowit i Światowid, była najważniejszym bóstwem wczesnych Słowian - Ranów. Tymczasem ze śląskimi i górniczymi wierzeniami związany jest Skarbnik (Skarbek) - duch zamieszkujący kopalnie, który sprawuje opiekę nad górnikami oraz dba o zachowanie spokoju i porządku pod ziemią. Pomnik Skarbnika pojawił się przed Kopalnią Węgla Kamiennego „Janina” w Libiążu.

Obiekty tego typu również wytwarzają wizerunki przedsiębiorstw. Taki wizerunek może mieć dwie odsłony - negatywną i pozytywną. Ta pierwsza, podobnie jak w przypadku pomników ideologiczno-politycznych, dotyczy obrazu organizacji niesamodzielnej, kierującej się zewnętrznymi wpływami ideologicznymi, a nawet egzotycznej, mało poważnej czy wręcz zacofanej i śmiesznej, odwołującej się do czegoś, co nie istnieje, albo nie ma żadnego znaczenia w poważnym świecie. Monumenty te mogą też wytwarzać zgoła inny wizerunek - organizacji kierującej się głębszymi wartościami, kontynuującej tradycje związane z dawnymi wierzeniami.

\section{Podsumowanie}

Żeby stwierdzić, jakie wizerunki przedsiębiorstw w świadomości odbiorców wytworzyły pomniki tego typu organizacji, wśród lokalnej społeczności, należałoby przeprowadzić badania ilościowe (choćby ankiety), wsparte również badaniami jakościowymi (np. wywiadami pogłębionymi). Wyniki tego typu studiów byłyby dopełnieniem przeprowadzonych $\mathrm{w}$ niniejszym artykule analiz. Ich cel stanowiło znalezienie odpowiedzi na pytanie, jakie wizerunki przedsiębiorstw tworzą stawiane przez nie pomniki? Jak wspomniano, badania dotyczyły wizerunku wytwarzanego (komunikowanego), a nie wytworzonego (powstałego w świadomości odbiorców komunikatu). Ten drugi aspekt jest oczywiście tak samo ważny, ale, jak nadmieniono, wymaga odrębnego zainteresowania.

Nie było łatwym zadaniem wskazać, jakie wizerunki przedsiębiorstw wytwarzają ich pomniki, gdyż zadanie to wymagało pogłębionego podejścia interpretatywnego, a nie tylko analityczno-opisowego. Dzięki wstępnemu podejściu

\footnotetext{
${ }^{4}$ Brakuje wystarczających danych, by potwierdzić tę datę.
} 
analityczno-opisowemu uzyskano dość wyrazisty obraz tego, z jakich elementów zawartych w pomnikach wynikają wizerunki przedsiębiorstw, co jest punktem odniesienia tych wizerunków, na czym one się opierają. Dla przypomnienia, wyłoniono dziewięć różnych płaszczyzn wytwarzania wizerunków przedsiębiorstw Z wykorzystaniem pomników: 1) wizerunki oparte na trudnych doświadczeniach przedsiębiorstw; 2) wizerunki oparte na pamiątkach przedsiębiorstw; 3) wizerunki oparte na wybitnych jednostkach przedsiębiorstw; 4) wizerunki oparte na ludzkiej pracy; 5) wizerunki oparte na dokonaniach przedsiębiorstw; 6) wizerunki oparte na znakach handlowych przedsiębiorstwa; 7) wizerunki oparte na zaangażowaniu społecznym przedsiębiorstwa; 8) wizerunki oparte na zaangażowaniu politycznym przedsiębiorstw; 9) wizerunki oparte na metafizycznych wartościach przedsiębiorstw.

W ramach ustalonych płaszczyzn dokonano analizy porównawczej pomników przedsiębiorstw. Autor dokonywał tej analizy na bieżąco, w ramach omawiania poszczególnych dziewięciu płaszczyzn. Na tym etapie niezbędne okazało się podejście pogłębione, interpretatywne. Warto podkreślić, że zaprezentowane wizerunki organizacji są subiektywnym spojrzeniem na problem badawczy przez autora. Zdaje on sobie sprawę, że inny badacz mógłby dojść do własnych wniosków i wyróżnić odmienne wizerunki, należy jednak podkreślić, że powyższe analizy przeprowadzono z zachowaniem wszelkiej staranności i skrupulatności badawczej.

Podsumowując - zdaniem autora najbardziej charakterystycznym wykreowanym poprzez pomniki wizerunkiem jest obraz przedsiębiorstwa utrwalającego pamięć o sobie (świadczą o tym obiekty odnoszące się do ich trudnych doświadczeń, pamiątek, wybitnych jednostek, ludzkiej pracy i znaków handlowych). Na podkreślenie zasługuje także wizerunek przedsiębiorstwa dysponującego wyjątkowym i społecznie istotnym dziedzictwem kulturowym (budowany poprzez ich trudne doświadczenia, pamiątki, wybitne jednostki). Przedsiębiorstwa jawią się też jako część społeczeństwa, w którym działają (także związane to jest z ich trudnymi doświadczeniami, ale też pamiątkami, wybitnymi jednostkami, ludzką pracą, znakami handlowymi). Przedsiębiorstwa posiadają również wizerunek organizacji kierujących się humanistycznymi wartościami (ponownie powstaje on w oparciu o ich trudne doświadczenia, ludzką pracę oraz zaangażowanie społeczne). Należy też wyróżnić obrazy przedsiębiorstw zależnych od zewnętrznego wpływu (zaangażowanie polityczne przedsiębiorstw, metafizyczne wartości) i koniunkturalnych (również zaangażowanie polityczne przedsiębiorstw) oraz kierujących się transcendentalnymi wartościami (poprzez wykorzystywaną metafizyczną symbolikę).

Badania nad pomnikami przedsiębiorstw, a w szerszym ujęciu organizacji, mogą mieć bardzo duże znaczenie z punktu widzenia nauk o zarządzaniu. Ich analiza może być pomocna w nakreśleniu tożsamości organizacji, jak też przybliżyć jej kulturę organizacyjną. Pomniki mogą bowiem odnosić się do wartości, norm i założeń kulturowych organizacji. Mogą być także fizyczną reprezentacją krążących w organizacji opowieści (o ojcach założycielach i mitach założycielskich, o superprzywódcach, 
o superpracownikach i superdokonaniach). Same w są także bardzo istotnymi symbolami - pomniki mogą stanowić punkt wyjścia do poznania i zrozumienia znaczenia symbolicznej „tkanki” organizacji. To tylko wybrane możliwości aplikacji wiedzy o pomnikach organizacji do nauk o zarządzaniu. Możliwości jest na pewno znacznie więcej.

\section{Bibliografia}

Alvesson M. (1990), Organization: From Substance to Image, „Organization Studies”, Vol. 11, Issue 3, s. 373-394.

Banaszkiewicz M.(2011), Pamiątki turystyczne - w poszukiwaniu tożsamości, „Turystyka Kulturowa", nr 4, s. 4-16.

Babbie E. (2006), Badania społeczne w praktyce, tłum. A. Kloskowska-Dudzińska, Warszawa: Wydawnictwo Naukowe PWN

Budzyński W. (2008), Public relations. Strategia i nowe techniki kreowania wizerunku, Warszawa: Poltext.

Burrell G., Morgan G. (2005), Sociological Paradigms and Organizational Analysis: Elements of the Sociology of Corporate Life, Burlington: Routledge.

Eco U. (1973), Dzieło otwarte. Forma i nieokreśloność w poetykach współczesnych, tłum. J. Gałuszka, L. Eustachiewicz, A. Kreisberg, M. Oleksiuk, Warszawa: Czytelnik.

Filek J. (2006), Społeczna odpowiedzialność biznesu: Tylko moda czy nowy model prowadzenia gospodarczej?, Warszawa: Urząd Ochrony Konkurenci i Konsumentów.

Filipp E. (2012), Społeczna odpowiedzialność organizacji, [w:] B. Glinka, M. Kostera (red.), Nowe kierunki w organizacji i zarzadzaniu, Warszawa: Wolters Kluwer Polska, s. 95-113.

Griffin R.W. (1996), Podstawy zarządzania organizacjami, tłum. M. Rusiński, Warszawa: Wydawnictwo Naukowe PWN.

Hatch M.J. (2002), Teoria organizacji, tłum. P. Łuków, Warszawa: Wydawnictwo Naukowe PWN. Jemielniak D. (2008), Praca oparta na wiedzy. Praca w przedsiębiorstwach wiedzy na przykładzie organizacji high-tech, Warszawa: Wydawnictwa Akademickie i Profesjonalne.

Kall J., Kłeczek R., Sagan A. (2006), Zarządzanie marka, Kraków: Oficyna Ekonomiczna.

Kociatkiewicz J., Kostera M. (2013), Zarzadzanie humanistyczne. Zarys programu, „Problemy Zarządzania”, Vol. 11, nr 4 (44), s. 9-19.

Kostera M. (2003), Antropologia organizacji. Metodologia badań terenowych, Warszawa: Wydawnictwo Naukowe PWN.

Kostera M. (2012), Zarzadzanie na rynku doznań, [w:] B. Glinka, M. Kostera (red.), Nowe kierunki w organizacji i zarządzaniu, Warszawa: Wolters Kluwer Polska, s. 361-375.

Kostera M., Śliwa M. (2010), Nowe tendencje w badaniach międzykulturowych i badaniach kultury, [w:] A. Jelonek, B. Glinka (red.), Zarządzanie międzykulturowe, Kraków: Wydawnictwo Uniwersytetu Jagiellońskiego, s. 269-290.

Kostera M., Śliwa M. (2012), Zarządzanie w XXI wieku, Warszawa: Wolters Kluwer Polska. Kotler P. (1994), Marketing. Analiza, planowanie, wdrażanie i kontrola, Warszawa: Gebethner i S-ka. Kotler P., Keller K.L. (2018), Marketing, Poznań: Rebis. 
Kożuch B. (2010), Nauka o organizacji, Warszawa: Cedewu.

Krajewski M, (2005), Wstęp, [w:] M. Krajewski (red.), W stronę socjologii przedmiotów, Poznań: Wydawnictwo Naukowe UAM, s. 7-9.

Laberschek M. (2018), Symboliczne stanowienie władzy w organizacjach, Kraków: Wydawnictwo Uniwersytetu Jagiellońskiego.

Macalik J. (2013), Logotyp jako podstawowy element identyfikacji wizualnej miasta - wybrane problemy, „Zeszyty Naukowe Wyższej Szkoły Bankowej we Wrocławiu”, nr 33, s. 147-161.

Oleksyn T. (2013), Kreatorzy zarzadzania, [w:] T. Oleksyn (red.), Filozofia a zarzadzanie, Kraków: Wolters Kluwer Polska.

Rok B. (2004), Odpowiedzialny biznes w nieodpowiedzialnym świecie, Warszawa: Akademia Rozwoju Filantropii w Polsce - Forum Odpowiedzialnego biznesu.

Schmitt B., Simonson A. (1999), Estetyka w marketingu. Strategiczne zarządzanie markami, tożsamością i wizerunkiem firmy, tłum. M. Bernacki, Kraków: Wydawnictwo Profesjonalnej Szkoły Biznesu.

Sedláček T. (2012), Ekonomia dobra i zła, tłum. D. Bakalarz, Warszawa: Wydawnictwo Studio Emka. Słownik języka polskiego (2007), oprac. L. Drabik i in., Warszawa: Wydawnictwo Naukowe PWN. Śnieżko D. (2013), Pamiątka, „Autobiografia. Literatura. Kultura. Media”, nr 1, s. 99-108.

Sułkowski Ł. (2012), Epistemologia i metodologia zarządzania, Warszawa: Polskie Wydawnictwo Ekonomiczne.

Sułkowski Ł. (2016), Teorie, paradygmaty, metafory i ideologie zarządzania - kontrowersje wokót wspótczesnego dyskursu organizacji i zarządzania, „Prace Naukowe Uniwersytetu Ekonomicznego we Wrocławiu”, nr 422, s. 131-143.

Sztompka P. (2006), Socjologia wizualna. Fotografia jako metoda badawcza, Warszawa: Wydawnictwo Naukowe PWN.

Turner B.A. (1986), Sociological Aspects of Organizational Symbolism, „Organization Studies”, Vol. 7, Issue 2, s. 101-115.

Waszkiewicz A. (2011), Wizerunek organizacji. Teoria i praktyka badania wizerunku uczelni, Warszawa: Instytut Dziennikarstwa Uniwersytetu Warszawskiego.

\section{Netografia}

Biesiekierz, https://pl.wikipedia.org/wiki/Biesiekierz.

Miał wiedzę, wizję i odwagę. Jako pierwszy w kraju zaczął produkować keczup, https://otopanorama.pl/mial-wiedze-wizje-odwage-jako-pierwszy-kraju-zaczal-produkowac-keczup/.

Odsłonięcie hutniczego pomnika, http://www.arcelormittal-warszawa.com/aktualnosci/odsloniecie-hutniczego-pomnika.

Patron kierowców w nowym miejscu, http://www.karuzelaturek.com.pl/?p=738

Przemyst, https://pl.wikipedia.org/wiki/Przemys\%C5\%82. 